\title{
Annona muricata Leaves Extract Reduce Proliferative Indexes and Improve Histological Changes in Rat's Breast Cancer
}

\author{
Evy Sulistyoningrum ${ }^{1 *}$, Eka Prasasti Nur Rachmani ${ }^{2}$, Hanif Nasiatul Baroroh ${ }^{3}$, Lantip Rujito ${ }^{4}$ \\ ${ }^{1}$ Department of Histology, Faculty of Medicine, Islamic University of Indonesia, Jl. Kaliurang, KM 14,5, Ngaglik, Sleman, Yogyakarta, 555834, Indonesia. \\ ${ }^{2}$ Department of Biological Pharmacy, Pharmacy School, Faculty of Health Sciences, Jenderal Soedirman University, Jl. Dr.Soeparno-Karangwangkal, \\ Purwokerto, Central Java, 53122, Indonesia. ${ }^{3}$ Department of Pharmacology, Pharmacy School, Faculty of Health Sciences, Jenderal Soedirman University, \\ Jl. Dr.Soeparno-Karangwangkal, Purwokerto, Central Java, 53122, Indonesia. ${ }^{4}$ Department of Molecular Biology, Faculty of Medicine, Jenderal Soedirman \\ University, Jl. Gumbreg No 1 Purwokerto, Central Java, 53112, Indonesia.
}

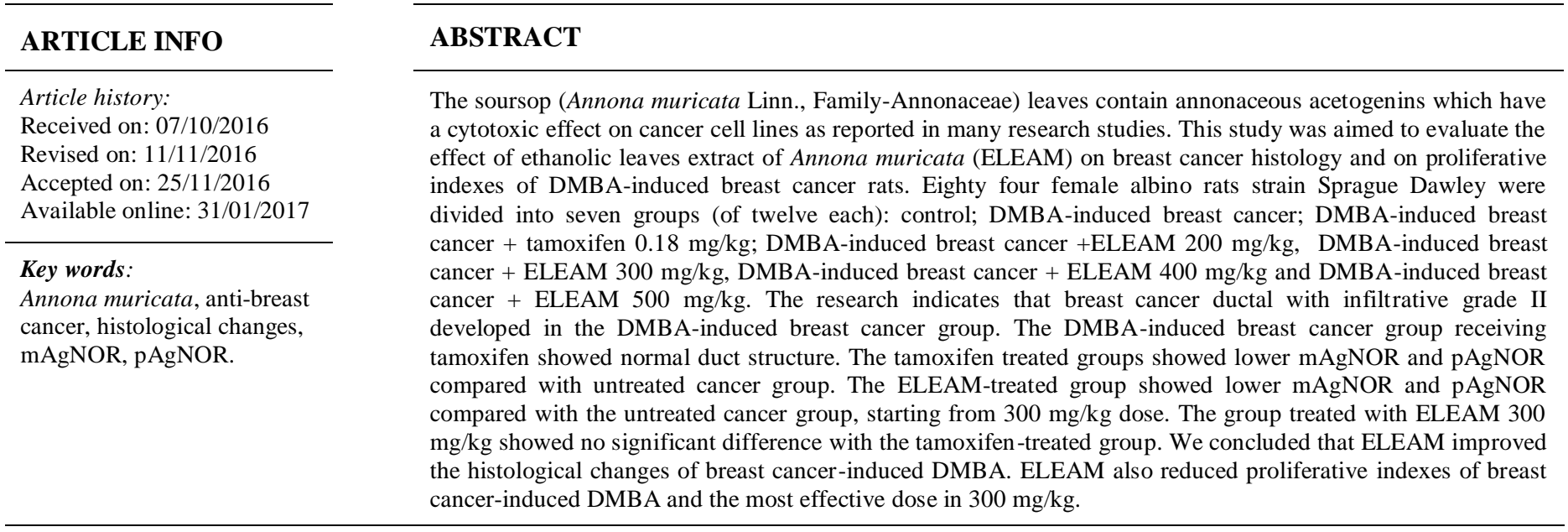

\section{INTRODUCTION}

Cancer is considered as one of the leading causes of morbidity and mortality worldwide. GLOBOCAN estimated that 14.1 million new cancer cases and 8.2 million cancer deaths occurred in 2012. Breast cancer is the most frequently diagnosed cancer in women and is considered the most lethal causing an estimated 1.7 million cases and 521,900 deaths in 2012. It accounts for $25 \%$ of all cancer cases and $15 \%$ of all cancer deaths

\footnotetext{
* Corresponding Author

Evy Sulistyoningrum, Department of Histology, Faculty of Medicine, Islamic University of Indonesia, Jl. Kaliurang, KM 14,5, Ngaglik, Sleman, Yogyakarta, 555834, Indonesia.

Email : evysulistyoningrum @ gmail.com
}

among females (Torre et al., 2015). The rates of cancer is expected to increase due to the growth and aging of the population and the adoption of behaviors and lifestyle which trigger cancer. According to the World Health Organization, there was 6.25 million new breast cancer patients every year and it has been predicted that there will be nine million deaths from cancer in the next ten years (WHO, 2014). Standard management of cancer (surgery, radiotherapy and chemotherapy) still has many problems, such as evident side effects and high economic loss, patient discomfort, hair loss, weight loss, nausea, vomiting, mucosal inflammation, and even serious conditions including infection and diabetes melitus. These side effects reduce a patient's quality of life and sometimes patients will decide to stop being involved in the management (deMartel et al., 2012). 
Therefore, cancer prevention is highly advantageous in cancer treatment since it is commonly believed to be preventable. Chemopreventive agents can be targeted for intervention at either the initiation stage, promotion or progression of carcinogenesis (Anand et al., 2008).

The use of natural products as anti-cancer agents has been incorporated into traditional and allopathic medicine (Mishra et al., 2013). Many cancer patients use herbal medicine as alternative medicines including phytochemicals in addition to, or following the failure of standard cancer therapy. Experimental studies indicate that phytochemicals with anti-oxidative and antiinflammatory properties can inhibit tumor initiation, promotion, and progression (Mishra et al., 2013). Therefore, the scientific validation of traditional medicine should be done for its possible use in the prevention and treatment of cancer.

Soursop (Annona muricata Linn), has been reported to have anticancer activity. It has been used traditionally to reduce tumor sizes and has minimal side effects. Gavamukulya and colleagues reported the phytochemical screening of the soursop extracts revealing that they contained secondary class metabolic compounds such as alkaloids, saponins, terpenoids flavonoids, coumarines and lactones, anthraquinones, tannins, cardiac glicosides, phenols and phytosterols (Gavamukulya et al., 2014). The ethanolic leaves extract was found to be selectively cytotoxic in vitro to tumor cell lines (EACC, MDA and SKBR3). Previous studies reported that soursop leaves extract has anti-breast cancer activity to T47D cell lines (Rachmani et al., 2012, Fidianingsih and Handayani, 2014). Ethanolic extract of Soursop (Annona muricata Linn) leaves also displayed a cytotoxic effect against MCF-7 (Endrini et al., 2014), HeLa cells, breast cancer cells (MCF-7) and lung cancer cells (A549) (Moghadamtousi et al., 2015). All the previous studies were performed in the in vitro setting, while the in vivo study of the extract has yet to be investigated or is limited. In the present study, protection effect of the ethanolic leaves extract of Annona muricata (ELEAM) on breast cancer induced by 7,12-dimethylbenzene[a]anthracene (DMBA) in an albino rat was examined.

\section{MATERIALS AND METHODS}

\section{Design of the study}

This post-test only with control group design was conducted in Integrated Research Testing of Gadjah Mada University and Jenderal Soedirman University, Indonesia.

\section{Plant material collection}

The Soursop leaves were taken from Sumbang District, Banyumas, Central Java, Indonesia. A voucher specimen (Number130601) was deposited at the Laboratorium of Biology Pharmacy of Jenderal Soedirman University.

The plant species was identified by the Plant Taxonomy Laboratory at the Biology Faculty of Jenderal Soedirman University, Purwokerto. The leaves were rinsed in tap water, dried in $50 \pm 1^{\circ} \mathrm{C}$ and ground into powder using a milling machine.

\section{Preparation of extracts}

To obtain the extract, $1000 \mathrm{~g}$ of the ground material was macerated with 5.5 liters $96 \%$ ethanol for 24 hours. The filtrate was collected using Whatman No. 1 filter paper and the residue was re-extracted with ethanol of 5.5 liters. Filtrate from four days of ethanol extraction was collected and evaporated by rotary evaporation. With $14 \%$ rendement, the extract obtained from this process was 141.7 grams. The extracts were kept in a clean glass jar at $4{ }^{\circ} \mathrm{C}$ from which aliquots were withdrawn for the test procedures.

\section{Animals}

A total of 84 healthy female rats (Rattus norvegicus strain Sprague Dawley) aged four weeks and weighing 8.0-100 grams were housed under group cages. The cages were kept occupied in laboratory conditions of $28-32^{\circ} \mathrm{C}$ temperature and $30 \%$ relative humidity and 12 hours light-dark cycle. Animals had free access to a standard pellet diet and mineral water. Rats were adapted for seven days and then divided into seven intervention groups (each group consisting of twelve rats): a control group received only distilled water; a DMBA-induced breast cancergroup; DMBA-induced cancer + tamoxifen $0.18 \mathrm{mg} / \mathrm{kg}$, DMBA-induced cancer+ ELEAM $200 \mathrm{mg} / \mathrm{kg}$, DMBA-induced cancer+ ELEAM $300 \mathrm{mg} / \mathrm{kg}$, DMBA-induced cancer+ ELEAM $400 \mathrm{mg} / \mathrm{kgand}$ DMBA-induced cancer+ ELEAM $500 \mathrm{mg} / \mathrm{kg}$. Tamoxifen and extract treatments were conducted orally every 9 AM for fourteen days, after which animals were sacrificed. Each rat was checked by inspection and palpation. Breast nodules were taken for histological staining. Ethical approval for this study was obtained from the Research Ethics Committee, Faculty of Medicine, Gadjah Mada University No.KE/FK/794/EC.

\section{Induction of cancer}

Cancer was induced by DMBA $20 \mathrm{mg} / \mathrm{kg}$, twice a week for five weeks orally. Rats were free from any treatment after induction for ten days before tamoxifen and AM extract treatments started as described in the Cancer Chemoprevention Research Center (CCRC), Gadjah Mada University Protocol.

\section{Histological preparation and examination}

Breast nodules from each animal were removed and placed in $10 \%$ buffer formalin, cast in paraffin followed by sectioning and staining with Hematoxylin-Eosin for the microscopic morphology visualization. Breast tissue stained with HE were examined based on WHO criteria for breast cancer, performed by Nikon ${ }^{\circledR}$ Eclipse E100 (NY, USA) with Optilab ${ }^{\circledR}$ Viewer (Yogyakarta, Indonesia). For AgNOR staining, isolated organs were sectioned and rehydrated with ethanol, then prepared with one volume gelatin $2 \%$ in formic acid $1 \%$ and two volume of AgNO3 $25 \%$ in 37 OC for eleven minutes. At $1000 \mathrm{x}$ magnification, a black dot per cell, $\mathrm{mAgNOR}$ and $\mathrm{pAgNOR}$ were calculated. mAgNOR signs were achieved by calculation of black dots mean in 100 cells nuclei, whereas the pAgNOR value were 
calculated by counting the percentage of nuclei exhibiting five or more AgNOR dots/100 cells (Bukhari et al., 2007).

\section{Statistical analysis}

Normally distributed data was expressed as mean \pm SD and analyzed using one way ANOVA whose results were further subjected to LSD post hoc test for multiple comparisons. If data were not distributed normally, a nonparametric test was performed. All analyses were performed with SPSS 15.00 software for Windows and the differences between means were accepted as significant at $\mathrm{p}<0,05$.

\section{RESULTS}

Research for investigating the effect of Annonna muricata leaves extract on breast cancer was conducted for eight weeks. The control group receiving only distilled water showed normal breast tissue with edematous stroma and normal tubular structure of gland lined by simple to stratified cuboidal epithelium (Figure 1A). This was similar with the DMBA-induced breast cancer group which also expressed edematous stroma, but the gland's structure was transformed into a tumor cell and the tumor cell showed stromal infiltration. The tamoxifen treated group showed edematous stroma, normal tubular structure of glands similar to the control group. Abnormal gland structure and stromal infiltration appeared in the ELEAM treated group receiving 200 $\mathrm{mg} / \mathrm{kg}$, however, the groups receiving either ELEAM $300 \mathrm{mg} / \mathrm{kg}$, $400 \mathrm{mg} / \mathrm{kg}$ or either $500 \mathrm{mg} / \mathrm{kg}$ ELEAM treatment indicated normal tubular glands structure and no stromal infiltration. Histological changes of breast tissue with haematoxylin eosin staining in lower magnification is illustrated on Figure 1. Figure 2 presents a higher magnification of breast glands cell in the normal structure derived from the control group and cancerous transformed group. In normal cell, cells had uniform morphology and their nuclei had no activity of abnormal mitosis index and nucear pleiomorphism. This kind of cell morphology was also found in the tamoxifen group and ELEAM group of $300 \mathrm{mg} / \mathrm{kg}$, $400 \mathrm{mg} / \mathrm{kg}$ and $500 \mathrm{mg} / \mathrm{kg}$. In the DMBA and ELEAM group of $200 \mathrm{mg} / \mathrm{kg}$, the gland's cell structure indicated pleiomorphic nuclei, hyperchromated and prominent nuclei and high mitosis index (Figure 2B). Proliferative indexes were calculated by examining AgNOR staining using mAgNOR (counting the mean of blackdots in 100 cell nuclei) and pAgNOR (percentage of cells exhibiting five or more blackdots in 100 cell nuclei). mAgNOR in the cancer group is the highest among others $(\mathrm{p}<0.05)$, treatment with tamoxifen and AM significantly reduced $\mathrm{mAgNOR}(\mathrm{p}<0.05$, compared with the untreated cancer group). All groups receiving AM extract indicated lower mAgNOR, but only the group receiving $300 \mathrm{mg} / \mathrm{kgAM}$ extract showed any obvious difference with the tamoxifen group (Figure 3). pAgNOR in the untreated cancer group is the highest ( $\mathrm{p}<0.05$ ). Treatment with tamoxifen or ELEAM significantly reduced pAgNOR $(\mathrm{p}<0.05$, compared with that of the untreated cancer group). Only groups receiving 300 $\mathrm{mg} / \mathrm{kg}$ ELEAM showed no difference in pAgNOR with the tamoxifen treated group (Figure 4). Representative figures showing blackdots in nuclei are presented in Figure 5.
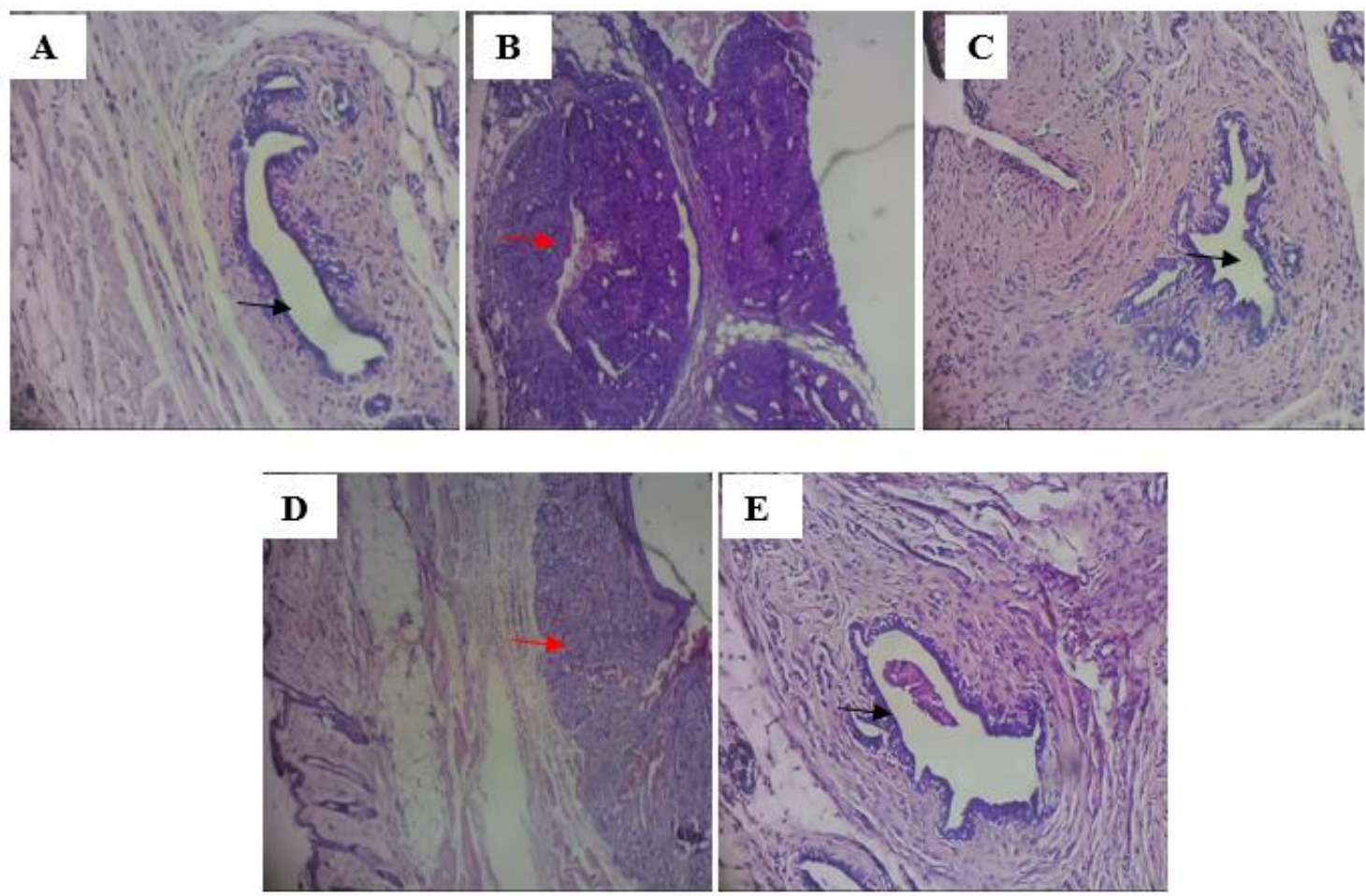

Fig. 1: Histological changes in groups of animals, lower magnification. Control group (A), DMBA-induced breast cancer group (B),DMBA-induced cancer + tamoxifen 0,18 mg/kg (C), DMBA-induced cancer + ELEAM $200 \mathrm{mg} / \mathrm{kg}$ (D), DMBA-induced cancer+ ELEAM $300 \mathrm{mg} / \mathrm{kg}$ (E). Black arrow showed normal architecture of glands while red arrow showed gland transformation into tumor cells, Hematoxylin Eosin, 100X. 


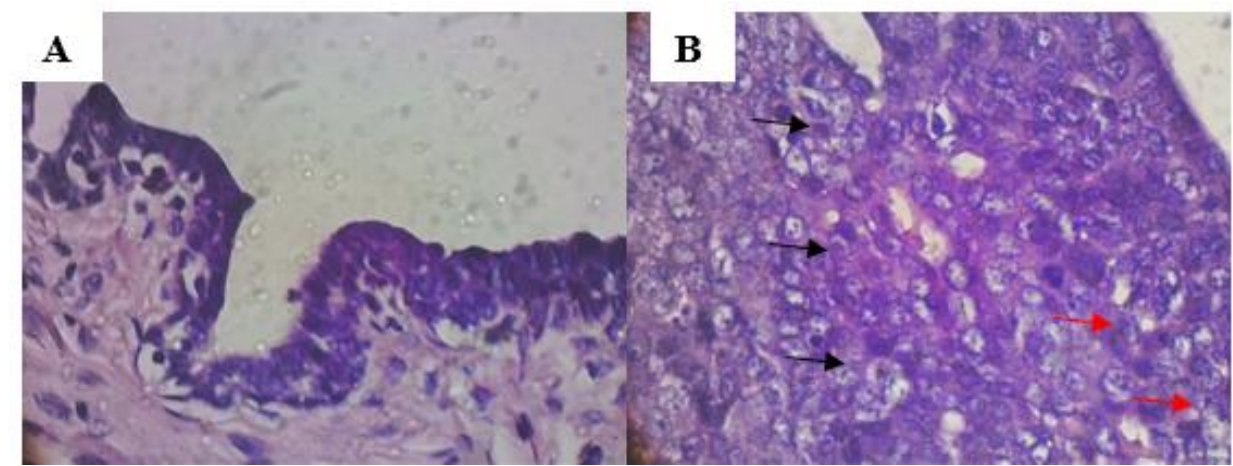

Fig 2. High magnification to show nuclear changes in cells. Normal gland cells showed single nucleus (A), while cancerous cells exhibits pleiomorphic nuclei, hyperchromated and prominent nuclei and high mitosis activity (B). Black arrow showed various shapes in nuclei (pleiomorphic) and red arrows showed mitosis, Hematoxylin Eosin, 400X.

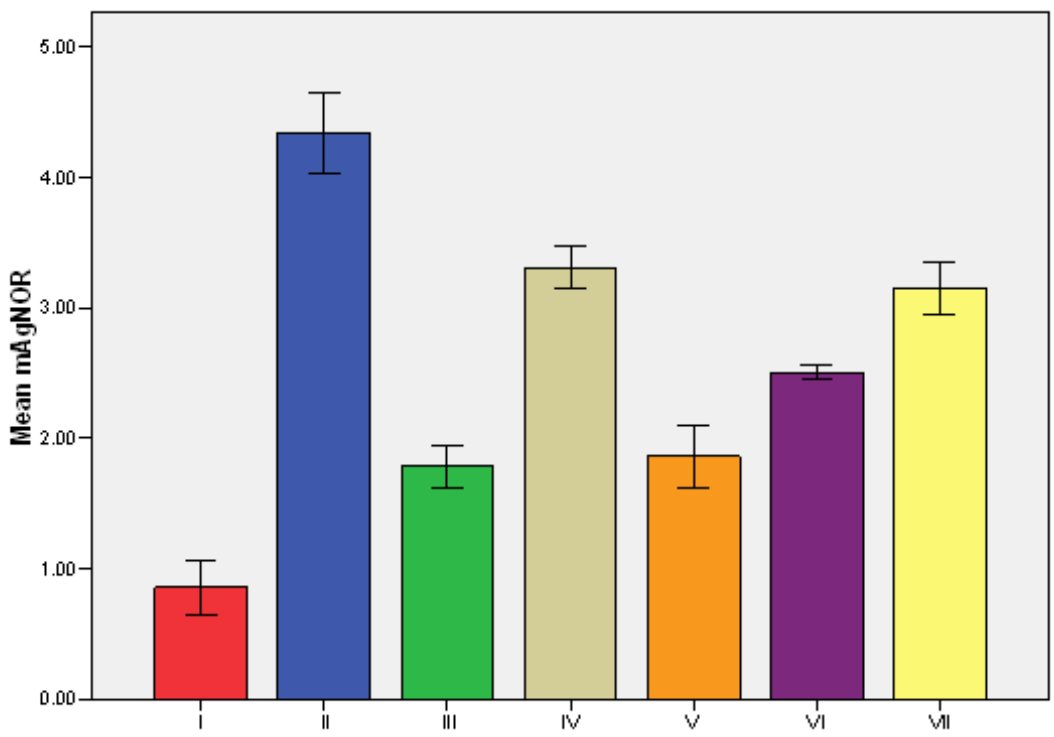

Fig 3. $\mathrm{mAgNOR}$ in each group, $\mathrm{n}=4$, Values in mean + Standard deviation, $* \mathrm{p}<0,05$ compared with group II, , \# $\mathrm{p}<0,05$ compared with group III (ANOVA followed by posthoc LSD). Group I: control group, Group II: DMBA-induced breast cancer group, Group III:DMBA-induced cancer + tamoxifen $0,18 \mathrm{mg} / \mathrm{kg}$, Group IV: DMB A-induced cancer + ELEAM $200 \mathrm{mg} / \mathrm{kg}$, Group V: DMBA-induced cancer+ ELEAM $300 \mathrm{mg} / \mathrm{kg}$, Group VI: DMBA-induced cancer+ ELEAM $400 \mathrm{mg} / \mathrm{kg}$ and Group VII: DMBA-induced cancer+ ELEAM $500 \mathrm{mg} / \mathrm{kg}$.

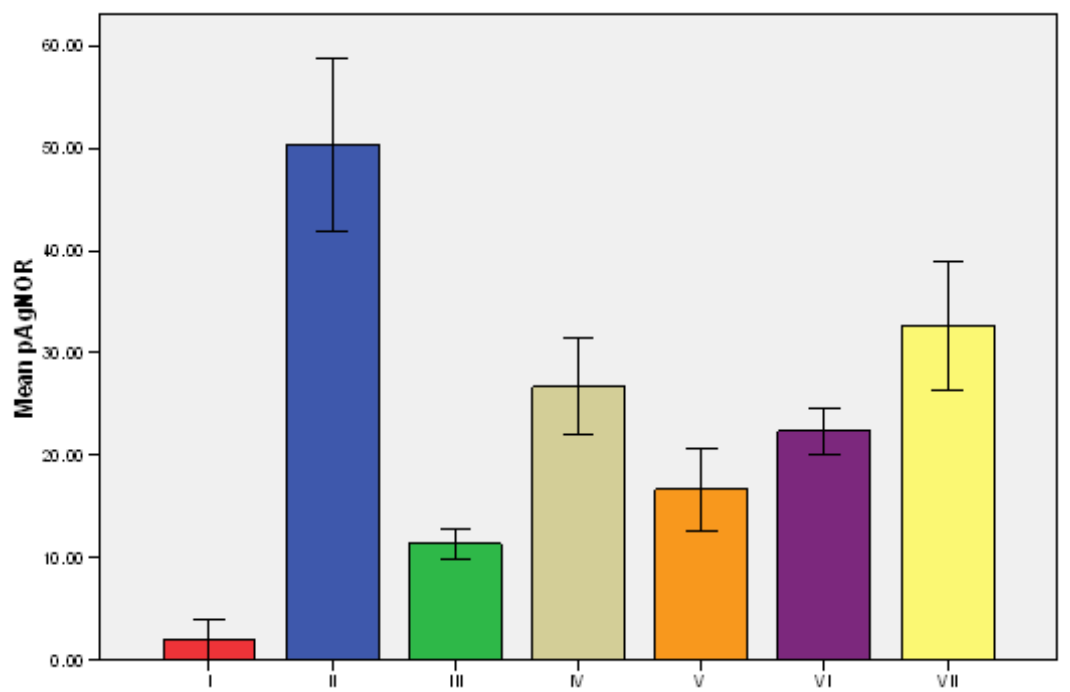

Fig. 4. pAgNOR in each group, $n=4$, Values in mean + Standard deviation, $* p<0,05$ compared with group II, , \# $p<0,05$ compared with group III (ANOVA followed by posthoc LSD). Group I: control group, Group II: DMBA-induced breast cancer group, Group III:DMBA-induced cancer + tamoxifen $0,18 \mathrm{mg} / \mathrm{kg}$, Group IV: DMBA-induced cancer + ELEAM 200 mg/kg, Group V: DMBA-induced cancer+ ELEAM 300 mg/kg, Group VI: DMBA-induced cancer+ ELEAM $400 \mathrm{mg} / \mathrm{kg}$ and Group VII: DMBA-induced cancer+ ELEAM $500 \mathrm{mg} / \mathrm{kg}$. 


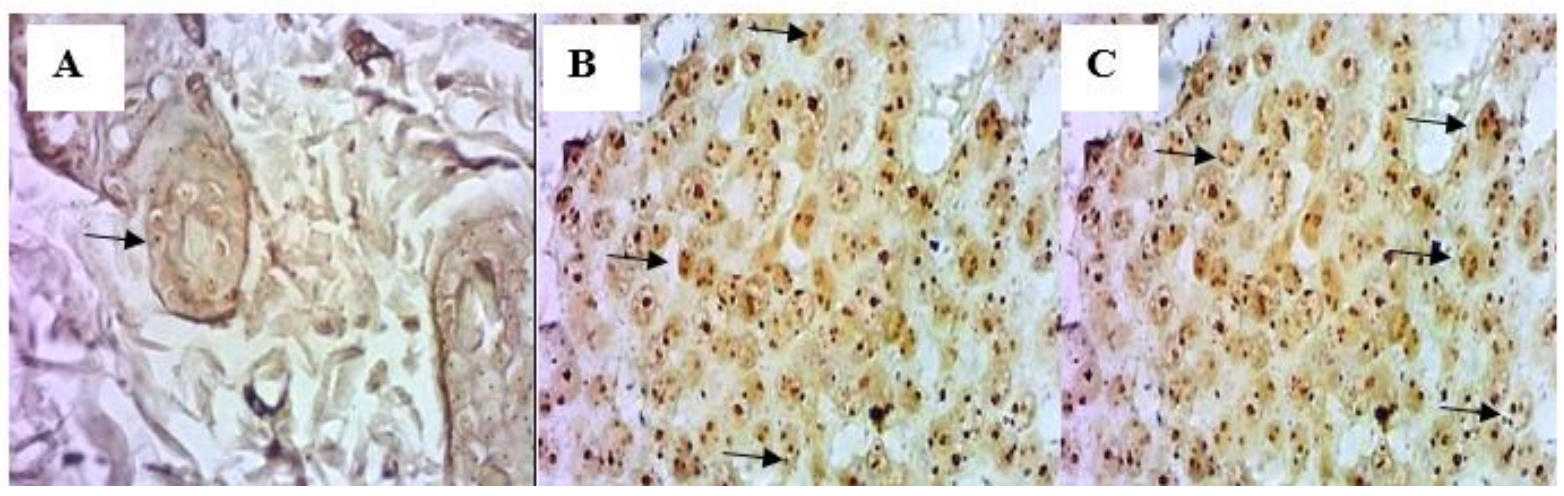

Fig 5: Blackdots in nuclei stained with AgNOR. Nuclei exhibit 0-1 dot.

(a), nuclei exhibit 3-4 dots (b), nuclei exhibit 4-6 dots (c). Arrows showed blackdots. AgNOR staining, 1000X.

\section{DISCUSSION}

Breast cancer has become one of the diseases with a high mortality rate. Novel treatment of cancer which has selective effects and low cost is needed to improve a patient's quality of life. This research points-out that Soursop (Annona muricata) leaves extract improves the breast histological appearance of DMBA-induced rats. DMBA is a well-known potent carcinogen which has been used to induce carcinogenesis in the mammary gland of experimental rodents such as rats and mice (Saha and Hait, 2012). Our study reveals that rats induced by DMBA exhibit breast nodules with various sizes starting at about four weeks after DMBA administration. The nucleus plays an essential role in the control of proliferation and protein synthesis.

AgNORs are loops of DNA which contain ribosomal rRNA genes and are stained by silver colloidal technique in which they are transcribed by RNA polymerase I. NORs located on the short arm of chromosome 13, 14, 15, $21 \& 22$ are of vital importance for ultimate synthesis of protein. Quantification of these portions has been a useful maker in differentiating benign, pre malignant, and malignant lesions. NORs are seen to be useful in diagnosing pre-malignant and malignant lesions of gallbladder, prostate, stomach, colon, cervix endometrium, ovaries, skin, mesothelium, breast, CNS, NHL. NORs appear as black dots of metallic silver about $0.5-1 \mu \mathrm{m}$ diameter localized within secondary constrictions of metaphase chromosome or in nuclei (Bukhari et al., 2007). AgNOR correlates with the rate of proliferation. Cancerous tissue has many characteristics, one of which is higher cell proliferation. Our study proves that the DMA-induced group had the highest mAgNOR and pAgNOR of the DMBA (Figure 3 and 4).

This research confirmed that treatment with DMBA for four weeks induced cancerous breast nodules and tissue transformation. This is consistent with a previous study that reported tumorogenesis of DMBA, not only in breast tissue, but also in papilloma in the hind limbs of a mouse treated with DMBA only. DMBA induced lobular alveolar hyperplasia, adenomatoid hyperplasia, fibro adipose stroma, and proliferating sebaceous gland of breast tissue in DMBA-treated mice (Minari and Okeke, 2014). The survival rate of the animal is low at week five, which might be triggered by the toxicity effect of DMBA. The other study reported the immunotoxicity of DMBA given to experimental animals to induce mammary glands (Miyata et al., 2001).

Treatment with Annona muricata improved the histological changes of breast tissue and reduced the proliferative indexes of their cells. Leaf extract of A. muricata prevented cellular proliferation in cancer induced by DMBA, possibly by interacting with DNA or DNA-binding proteins. This interaction triggers DNA damage signaling pathways resulting in the inhibition of cell proliferation or the induction of apoptosis, depending on the extent of the damage.

The preventive effect of an ethanolic extract of $A$. muricata leaves against DMBA-induced DNA damage could be due to the presence of the various secondary metabolites (tannins, terpenoids, cardiacglycosides, and flavonoids) discovered from the phytochemical screening of the ethanolic extract of A. Muricata (Minari and Okeke, 2014). In addition, A. muricata leaves extract also suppressed tumor initiation on the development of melano carcinoma induced by DMBA in mice, as reported in a previous study. Groups treated with topical AM extract have lower incidence and reduced tumor volume compared with that of DMBA. On histological study, AM treated groups also exhibited only slight hyperplasia and absence of keratin pearls and rete ridges instead of carcinoma (Hamizah et al., 2012).

This data was in line with previous in vitro studies; the leaves of soursop had in vitro anticancer activity on T47D cell lines (Rachmani et al., 2012), human adenocarcinoma cell MCF-7 (Ko et al., 2011), human carcinoma cell (MDA-MB-435S) or human immortal keratino cytes (HaCaT) (George et al., 2012).

The antiproliferative activity of $A$. muricata extract had been also reported elsewhere. A comprehensive study showed that potentially strong antiproliferation and apoptosis was achieved through disruption of MMP (Membrane mitochondrial potential), reactive oxygen species (ROS) generation and G0/G1 phase cell 
arrest of Human promyelocytic leukemia (HL-60 cells) cell culture (Pieme et al., 2014). Using HCT-116 and HT-29 cells and MTT and LDH assays, it has been shown that cells treated by EEAM arrested in G1 cell cycle phase and induced to apoptosis cascade. EEAM treatment caused excessive accumulation of ROS followed by disruption of MMP, cytochrome c leakage and activation of the initiator and executioner $\mathrm{c}$ as passes in both colon cancer cells (Moghadamtousi et al., 2014b). It's also reported that ethyl acetate extract of A. muricata inhibited the proliferation of A549 cells, leading to cell cycle arrest and programmed cell death through activation of the mitochondrial-mediated signaling pathway with the involvement of the NF- $\mathrm{KB}$ signalling pathway (Moghadamtousi et al., 2014a).

The most effective dose in reducing cancer proliferative indexes based on mAgNOR and pAgNOR is $300 \mathrm{mg} / \mathrm{kg}$, which has a similar effect with tamoxifen. The data replicated a previous study which noted that the effective dose of AM leaves extract for cytotoxic and antiproliferative activity is $200 \mathrm{mg}$ and $300 \mathrm{mg}$, but in $200 \mathrm{mg}$, the tissue still showed hyperplasia (Hamizah et al., 2012). Recent studies reported that AM leaves extract has a cytotoxic effect because it contains annonaceous acetogenins. These acetogenins would inhibit mitochondrial complex I which further can reduce intracellular ATP production leading to cellular apoptosis.

Reduced ATP also induced intracellular hypoxia which further activates Tumor Supressor Genes p53. Activation of these genes will stop cell cycle on G1 phase so that cancer cell proliferation can be prevented (Gajalakshmi et al., 2012).

There are many forms of annonaceous acetogenin in soursop leaves, some of which are annomuricin and muricapentocin which have selective effect on human cancer cells. Soursop leaves also contain muricoreacin and murihexocin which had a cytotoxic effect on cancer cells (Alvarez-Gonzalez et al., 2008). The other acetogenins in soursop is tetrahydrofuran acetogenins such as solamin A which had a selective anticancer effect (Coria-Téllez et al., 2016).

\section{CONCLUSIONS}

In brief, it can be concluded that Annona muricata leaves extract improved the histological changes of breast cancer-induced DMBA. Induction of DMBA elevated proliferation indexes of mAgNOR and pAgNOR. Moreover, Annona muricata leaves extract reduced proliferative indexes of breast cancer-induced DMBA and the most effective dose is in $300 \mathrm{mg} / \mathrm{kg}$. Since the development of drug delivery technology has grown rapidly, it is promising substances developed in the near future.

\section{ACKNOWLEDGEMENTS}

We express our gratitude to Mr. Hidayat Sulistyo for providing us with endless support throughout the research.

Financial support and sponsorship: This research study was funded by a Competitive Research Grant by Ministry of Research, Technology and Higher Education, Indonesia.
Conflict of Interests: There are no conflicts of interest.

\section{REFERENCES}

Alvarez-Gonzalez I., García-Aguirre KK., Martino-Roaro L., Zepeda-Vallejo G., Madrigal-Bujaidar E. Anticarcinogenic and genotoxic effects produced by acetogenins isolated from Annona muricata. Toxicol Lett, 2008; 180: Supplement, S228.

Anand P., Sundaram C., Jhurani S., Kunnumakkara AB., Aggarwal BB. Curcumin and cancer: An "old-age" disease with an "ageold" solution. Cancer Lett, 2008; 267 (1): 133-164.

Bukhari MH., Niazi S., Khan SA., Hashmi I., Perveen S., Qureshi SS., Chaudhry NA., Qureshi GR., Hasan M. Modified method of AgNOR staining for tissue and interpretation in histopathology. Int J Clin Exp, 2007; 88 (1):47-53.

Coria-Téllez AV., Montalvo-Gónzalez E., Yahia EM,. ObledoVázquez EN. Annona muricata: A comprehensive review on its traditional medicinal uses, phytochemicals, pharmacological activities, mechanisms of action and toxicity. Arab J Chem, 2016; available at: http://dx.doi.org/10.1016/j.arabjc.2016.01.004

de Martel C., Ferlay J., Franceschi S., Vignat J., Bray F., Forman D., Plummer M. Global burden of cancers attributable to infections in 2008: a review and synthetic analysis. Lancet Oncol, 2012;13 (6): 607-615.

Endrini S., Suherman S., Widowati WUM. Annona muricata leaves have strongest cytotoxic activity against breast cancer cells. Universa Medicina, 2014; 33 (3): 179-184.

Fidianingsih I., Handayani E. Annona muricata aqueous extract suppresses T47D breast cancer cell proliferation. Universa Medicina, 2014;33 (1): 19-26.

Gajalakshmi S., Vijayalakshmi S., Rajeswari DV. Phytochemical And Pharmacological Properties Of Annona muricata: A Review. Int J Pharm Pharm Sci, 2012;4 (2): 3-6.

Gavamukulya Y., Abou-Elella F., Wamunyokoli F., Ael-Shemy $\mathrm{H}$. Phytochemical screening, anti-oxidant activity and in vitro anticancer potential of ethanolic and water leaves extracts of Annona muricata (Graviola). Asian Pac J Trop Med, 2014;7: S355-S363.

George VC., Kumar DRN., Rajkumar V., Suresh PK., Kumar RA. Quantitative Assessment of the Relative Antineoplastic Potential of the n-butanolic Leaf Extract of Annona Muricata Linn. in Normal and Immortalized Human Cell Lines. Asian Pacific J Cancer Prev, 2012;13 (2): 699-704.

Hamizah S., Roslida AH., Fezah O., Tan KL., Tor YS., Tan CI. Chemopreventive Potential of Annona Muricata L Leaves on ChemicallyInduced Skin Papillomagenesis in Mice. Asian Pacific J Cancer Prev, 2012; 13 (6): 2533-2539.

Ko YM., Wu TY., Wu YC., Chang FR., Guh JY., Chuang LY. Annonacin induces cell cycle-dependent growth arrest and apoptosis in estrogen receptor- $\alpha$-related pathways in MCF-7 cells. J Ethnopharmacol, 2011; 137 (3):1283-1290.

Minari JB., Okeke U. Chemopreventive effect of Annona muricata on DMBA-induced cell proliferation in the breast tissues of female albino mice. Egypt J Med Hum Genet, 2014; 15 (4):327-334.

Mishra S., Ahmad S., Kumar N., Sharma BK. Annona muricata (the cancer killer): a review. Glob J Pharma Res, 2013;2:1613-1618

Miyata M., Furukawa M., Takahashi K., Gonzalez FJ.,Yamazoe Y. Mechanism of 7,12-Dimethylbenz anthracene-Induced Immunotoxicity: Role of Metabolic Activation at the Target Organ. Jpn J Pharmacol, 2001;86 (3): 302-309.

Moghadamtousi SZ., Fadaeinasab M., Nikzad S., Mohan G., Ali HM., Kadir HA. Annona muricata (Annonaceae): A Review of Its Traditional Uses, Isolated Acetogenins and Biological Activities. Int. J Mol Sci, 2015; (7): 15628-15625.

Moghadamtousi SZ., Kadir HA., Paydar M., Rouhollahi E., Karimian H. Annona muricata leaves induced apoptosis in A549 cells through mitochondrial-mediated pathway and involvement of NF- $\mathrm{KB}$. BMC Complement Altern Med, 2014; 14 (1): 1-13.

Moghadamtousi ZS., Karimian H., Rouhollahi E., Paydar M., Fadaeinasab M., Abdul Kadir H. Annona muricata leaves induce G1 cell 
cycle arrest and apoptosis through mitochondria-mediated pathway in human HCT-116 and HT-29 colon cancer cells. J Ethnopharmacol, 2014; 156: 277-289.

Pieme CA., Kumar SG., Dongmo MS., Moukette BM., Boyoum FF., Ngogang JY., Saxena AK. Antiproliferative activity and induction of apoptosis by Annona muricata (Annonaceae) extract on human cancer cells. BMC Complement Altern Med, 2014;14 (1): 1-10.

Rachmani EPN, Suhesti TS, Widiastuti R., Aditiyono A. The breast of anticancer from leaf extract of Annona muricata againts cell line in t47D. Int J Appl Sci Technol, 2012;2 (1):198-2003.

Saha D., Hait M. An Ontological Design: Two Stage Mouse Skin Carcinogenesis Induced By DMBA and Promoted By Croton Oil. Asian J Pharm Sci, 2012; 2 (1):1-3.

Torre LA., Bray F., Siegel RL., Ferlay J., Lortet-Tieulent J., Jemal A. Global cancer statistics 2012. CA Cancer J Clin, 2015; 65 (2): 87-108.

WHO 2014. World Cancer Report 2014, The International Agency for Research on Cancer (IARC), available at https://shop.iarc.fr/products/wcr2014 [Accessed 08 July 2015]

\section{How to cite this article:}

Sulistyoningrum E, Rachmani EPN, Baroroh HN, Rujito L. Annona muricata Leaves Extract Reduce Proliferative Indexes And Improve Histological Changes In Rat's Breast Cancer. J App Pharm Sci, 2017; 7 (01): 149-155. 